\title{
Peningkatan Kinerja Kader Posyandu dan Kualitas Pelayanan di Posyandu Lestari
}

\author{
${ }^{1}$ Umi Fadlilah, ${ }^{2}$ Gunawan Ariyanto, ${ }^{3}$ Sholeh Rudi Hartono, ${ }^{4}$ Erwan Tri Kurniawan, \\ ${ }^{5}$ Sadam Husein \\ 1,3,4,5 Program Studi Teknik Elektro, Fakultas Teknik, Universitas Muhammadiyah Surakarta \\ ${ }^{2}$ Program Studi Informatika, Fakultas Komunikasi dan Informatika, Universitas Muhammadiyah Surakarta \\ email: umi.fadlilah@ums.ac.id
}

\section{Article Info}

Submitted: 5 September 2019 Revised: 24 September 2019 Accepted: 10 Desember 2019 Published: 2 Januari 2020

Keywords: body length, body temperature, body weight, head circumference, measuring instrument, $P M T$
Kata kunci: alat ukur, berat badan, lingkar kepala, PMT, panjang badan, suhu badan
Abstract

This community service measures the reduction in posyandu for underfives babies on the measurement of 4 parameters, namely body weight, body length, head circumference, and body temperature. Therefore, the use of electronic measuring devices based on the Arduino Mega 2560 microcontroller is supported with load cell sensors, TN901 infrared sensors, and ultrasonic sensors that can be used to automatically display these parameters via an LCD (Liquid Crystal Display) screen that can help posyandu cadres to serve the community immediately. This electronic measuring instrument can display measurement results more accurately than manual measuring tools. The measurement time for each toddler only requires less than 5 minutes to produce the reading and recording of the previous parameters. Through this community service, we make and donate these measuring devices, as well as provide training to cadres of toddlers at integrated health centers on how to use them. Another assistance that we provide is financial donations for the provision of supplementary food (PMT) for posyandu participants, especially in Posyandu Lestari, Ngadijayan, Ngadirejo, Kartasura, Sukoharjo. The assistance is expected to support the improvement of posyandu cadres to be faster and more useful and to improve the quality of posyandu services. The measurement results of the 4 parameters using an Arduino Mega 2560 microcontroller-based electronic device are quite valid, practical, and time-saving, while the measurement value is not yet stable, especially in terms of temperature parameters

\footnotetext{
Abstrak

Pengabdian masyarakat ini bertujuan untuk mengurangi tingkat kesalahan pengukuran pada posyandu balita pada pengukuran 4 parameter, yaitu berat badan, panjang badan, lingkar kepala, dan suhu badannya. Oleh karena itu, penggunaan alat ukur elektronik
} 
berbasis mikrokontroler Arduino Mega 2560 didukung dengan sensor load cell, sensor infrared TN901, dan sensor ultrasonik yang dapat secara otomatis menampilkan keempat parameter tersebut melalui layar LCD (Liquid Crystal Display) diharapkan bisa membantu kader-kader posyandu untuk segera melayani masyarakat. Alat ukur elektronik tersebut bisa menampilkan hasil pengukuran yang lebih akurat dibandingkan dengan alat ukur manual. Waktu pengukuran untuk masing-masing batita hanya membutuhkan kurang dari 5 menit sampai menghasilkan pembacaan dan pencatatan keempat parameter tadi. Melalui pengabdian masyarakat ini, kami membuat dan menyumbangkan alat ukur tersebut, sekaligus memberi pelatihan terhadap kader posyandu balita tentang cara menggunakannya. Bantuan lain yang kami sampaikan adalah sumbangan dana untuk Pemberian Makanan Tambahan (PMT) bagi peserta posyandu, terutama di Posyandu Lestari, Ngadijayan, Ngadirejo, Kartasura, Sukoharjo. Bantuan-bantuan tersebut diharapkan bisa mendukung kinerja kader posyandu agar lebih cepat dan bermanfaat serta berdampak pada peningkatan kualitas pelayanan posyandu. Hasil ukur tentang 4 parameter menggunakan alat mukur elektronik berbasis mikrokontroler Arduino Mega 2560 tersebut cukup valid, praktis, dan menghemat waktu walaupun kadang nilai ukurnya belum stabil terutama dalam hal parameter suhu

\section{PENDAHULUAN}

Posyandu adalah suatu bentuk keterpaduan pelayanan kesehatan yang dilaksanakan di suatu wilayah kerja Puskesmas, dimana pelaksanannya dilakukan di tiap kelurahan atau RW (Rukun Warga). Kegiatannya berupa KIA (Kesehatan Ibu dan Anak), KB (Keluarga Berencana), Imunisasi dan Penanggulangan Diare, serta Gizi (dalam bentuk Penimbangan Balita). Sasarannya adalah ibu hamil, ibu menyusui, dan wanita usia subur (Muninjaya, 2004). Posyandu diselenggarakan dari, oleh, dan untuk masyarakat yang dibantu oleh petugas kesehatan setempat, dimana dalam 1 unit Posyandu, idealnya melayani sekitar 100 balita atau 120 kepala keluarga yang disesuaikan dengan kemampuan petugas dan keadaan setempat yang dibuka sebulan sekali, dilaksanakan oleh kader Posyandu terlatih di bidang KB, yang bertujuan mempercepat angka penurunan kematian bayi, anak balita, dan angka kelahiran. Memantau pertumbuhan Balita di posyandu merupakan upaya yang sangat strategis untuk mendeteksi dini terjadinya gangguan pertumbuhan (berdasarkan data dari Pusdatin Kemenkes RI, 2016). Selain bidan desa, juga ada kader-kader posyandu yang mendukung jalannya kerja posyandu. Peran kader posyandu sangat penting dalam mendukung program pemerintah untuk meningkatkan status gizi dan mengurangi status gizi buruk balita melalui kegiatan pemberdayaan masyarakat di posyandu (Mulat, 2017; Al Azizah, 2017). Keaktifan ibu pada setiap kegiatan di posyandu juga akan berpengaruh pada status gizi putra/putri balitanya (Utami dkk., 2014; Al Azizah, 2017).

Dewasa ini, di Indonesia ada Posyandu balita dan lansia (lanjut usia) yang dibawahi oleh bidan di masing-masing kelurahan atau desa. Pada pengabdian masyarakat ini, tim pengabdian melaksanakan pengabdian di Posyandu Balita Lestari di Kelurahan Ngadirejo Kecamatan Kartasura Kabupaten Sukoharjo, Jawa Tengah. Posyandu tersebut letaknya paling dekat dengan praktek bidan yang menangani 5 Posyandu di Kelurahan Ngadirejo.

Permasalahan umum yang dihadapi Posyandu Lestari antara lain:

a. Para kader Posyandu mengalami kesulitan saat mengukur dan menimbang bayi, sebab masih menggunakan perangkat manual yaitu timbangan gantung besi dan rotan, alat pengukur tinggi badan atau

Warta LPM, Vol. 23, No. 1, Maret 2020 
stature meter, alat pengukur lingkar kepala juga menggunakan stature meter, serta thermometer air raksa, sehingga hasilnya mungkin kurang tepat dan cepat. Posyandu juga belum mempunyai alat ukur otomatis yang langsung mengetahui 4 parameter kesehatan Batita. Ilustrasi alat ukur manual yang digunakan bisa dilihat pada Gambar 1 .

b. Para kader Posyandu harus meninggalkan pekerjaan utamanya karena tugas di Posyandu. Bila ada banyak peserta Posyandu, maka bisa jadi ada penurunan income atau penghasilan mereka pada hari itu, khususnya yang berprofesi sebagai wiraswasta.

Foto antrian di Posyandu Lestari dapat dilihat pada Gambar 2.

c. Dana PMT (Pemberian Makanan Tambahan) di Posyandu itu terbatas, sebab subsidi dari Puskesmas relatif sedikit dan hanya mendapatkan tambahan infaq sukarela dari peserta Posyandu/orang tua bayi dan balita saat mendaftarkan kehadiran putra/ putrinya di posyandu. PMT sangat penting diberikan kepada peserta Posyandu sebab peserta Posyandu dapat dilihat perkembangan tingkat gizinya sebelum maupun sesudah mendapatkan PMT agar tidak termasuk dalam kategori gizi buruk (Fitriyanti, dkk, 2012).

Dengan berjalannya program pengabdian ini, diharapkan mampu memberikan manfaat kepada kader Posyandu sehingga bisa menggunakan alat ukur 4 parameter kesehatan batita dan kader Posyandu pun bisa lebih meningkat kapasitasnya. Proses pengukuran dan penimbangan bayi pun akan lebih praktis, mudah, dan hemat waktu. Selain itu, unit Posyandu juga akan mendapatkan bantuan dalam menyediakan PMT secara gratis, sehingga hal ini dapat meningkatkan kualitas pelayanan di Posyandu. Sedangkan bagi orang tua, dengan menggunakan alat elektronik tersebut, maka hasil timbangan yang didapatkan lebih akurat dan proses antrian tidak berlangsung lama.
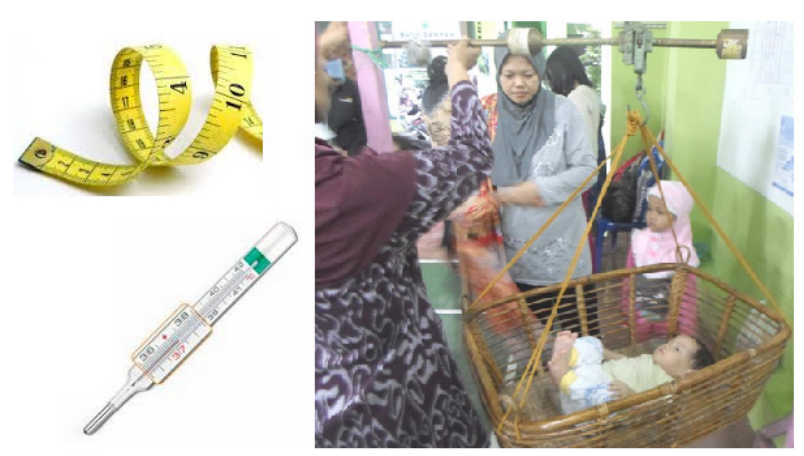

Gambar 1. Gambaran alat ukur manual di posyandu balita secara umum

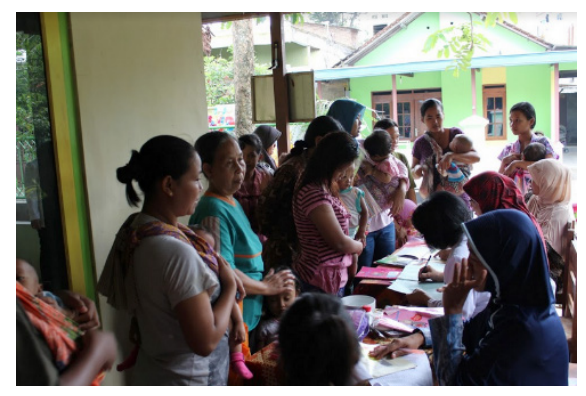

Gambar 2. Proses antri saat mendaftar di Posyandu Lestari

\section{METODE}

Berdasarkan permasalahan yang ada di Posyandu Lestari tersebut, maka tim pengabdian masyarakat ini berusaha turut memberikan solusi menggunakan metode sebagai berikut:

a. Mengikuti pertemuan dengan kader dari lima posyandu yang dihadiri oleh bidan desa setempat untuk mencari tahu permasalahan dalam layanan posyandu pada tiap bulan. Selanjutnya memutuskan untuk memilih salah satu posyandu sebagai tempat pengabdian masyarakat, yaitu Posyandu Lestari yang paling dekat dengan Kantor Kelurahan Ngadirejo.

b. Mengidentifikasi persoalan prioritas utama yaitu:

1) Para kader posyandu mengalami kesulitan saat mengukur dan menimbang batita, sebab masih menggunakan perangkat yang konvensional.

2) Para kader posyandu harus meninggalkan pekerjaan utamanya saat sedang bertugas di posyandu.

3) Dana PMT (Pemberian Makanan Tambahan) masih kurang. 
4) Belum ada alat ukur yang langsung mengetahui 4 parameter kesehatan bayi secara bersamaan.

c. Menawarkan dan menyepakati bersama antara tim pengabdian masyarakat dengan pihak posyandu tentang metode pendekatan untuk menyelesaikan permasalahan tersebut, yaitu:

1) Merancang dan membangun serta menyumbangkan satu alat ukur elektronik kepada Posyandu Lestari yang khusus untuk mengukur 4 parameter kesehatan batita (meliputi berat badan, panjang badan, lingkar kepala, dan suhu badan) agar hasil pengukurannya lebih cepat dan akurat.

2) Memberikan pelatihan kepada kader Posyandu Lestari tentang cara menggunakan alat ukur elektronik tersebut agar mereka lebih memahami dan bisa memanfaatkan alat itu dengan baik. Hal ini diharapkan bisa mengefisienkan waktu sehingga mereka bisa segera menyelesaikan tugas di posyandu serta melanjutkan tugas utamanya di lingkungan kerja masing-masing baik sebagai wanita karir maupun ibu rumah tangga.

3) Memberikan bantuan dana PMT untuk menambah kas Posyandu Lestari terutama dalam hal pelayanan makanan tambahan yang bergizi bagi balita pada umumnya, sebab di Posyandu Lestari diikuti oleh anakanak sebagai peserta di bawah usia lima tahun.

d. Prosedur kerja sekaligus rencana kegiatan solutif untuk melaksanakan metode pendekatan tersebut adalah dengan merancang dan membuat alat ukur elektronik untuk batita. Lalu menguji kinerja alat tersebut sampai menghasilkan nilai ukur dari keempat parameter yang tepat. Perancangan alat ukur empat parameter kesehatan batita ini dibagi menjadi 2 bagian yaitu perancangan hardware (perangkat keras) dan software (perangkat lunak).

\section{1) Perancangan Hardware}

Blok diagram perancangan hardware secara keseluruhan terdiri atas 3 bagian utama, yaitu blok input (masukan), prosesor (pemroses), dan output (keluaran). Blok input terdiri atas tombol, sensor suhu infrared TN901, sensor untuk berat badan yaitu berat Load cell, dan sensor ultrasonik untuk mengukur panjang badan serta lingkar kepala batita. Prosesornya menggunakan Arduino Mega 2560 dengan LCD 4 × 20 sebagai outputnya. Board Arduino Mega 2560 adalah sebuah Board Arduino yang menggunakan IC (Integraed Circuit) Mikrokontroler ATmega 2560. Board

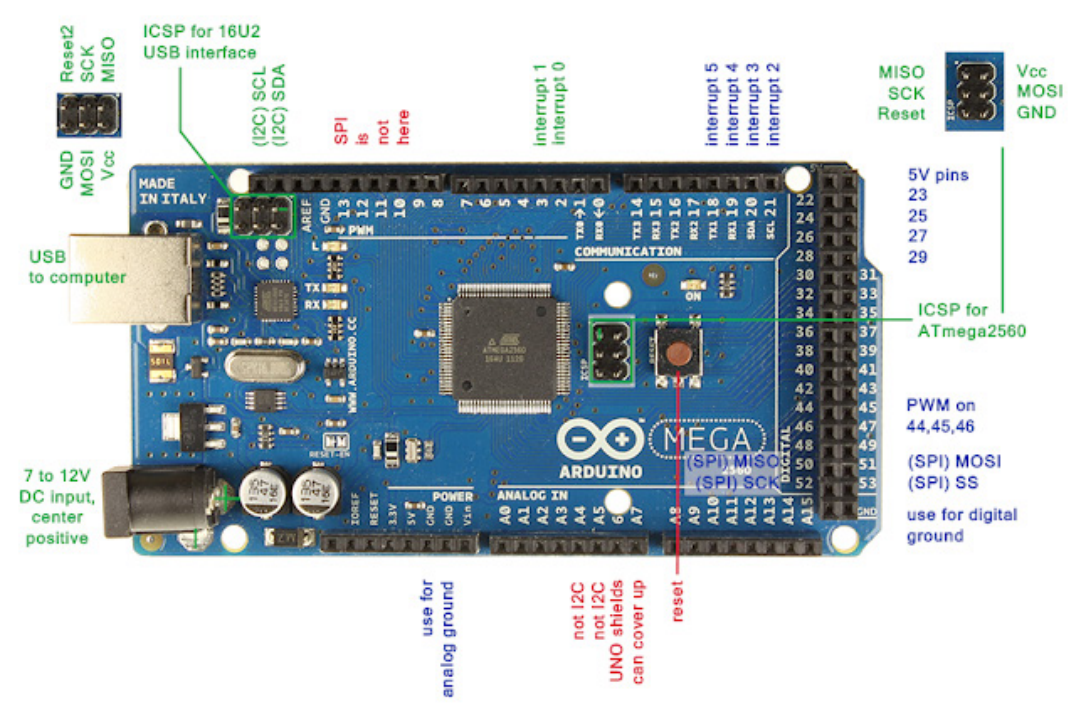

Gambar 3. Board Arduino Mega 2560

(Hartono, 2015) 
ini memiliki Pin I/O (Input/Output) yang relatif banyak, yaitu 54 digital Input/Output, 15 buah di antaranya dapat digunakan sebagai output PWM (Pulse Wave Modulation), 16 buah analog Input, dan 4 UART (Universal Asynchronous Receiver-Transmitter). Arduino Mega 2560 dilengkapi dengan kristal 16 Mhz. Arduino Mega 2560 dihubungkan ke power dari USB (Universal Serial Bus) ke PC (Personal Computer)/Laptop atau melalui Jack DC (Direct Current) menggunakan adaptor 7-12 volt DC. Board Arduino Mega 2560 blok diagram alat ini dapat dilihat pada Gambar 3.

Berdasarkan Gambar 3 dapat diketahui beberapa spesifikasi dari Board Arduino Mega 2560 tersebut.

Adapun blok diagram alat ukur yang menampilkan 4 parameter kesehatan batita dapat diketahui dari Gambar 4 .

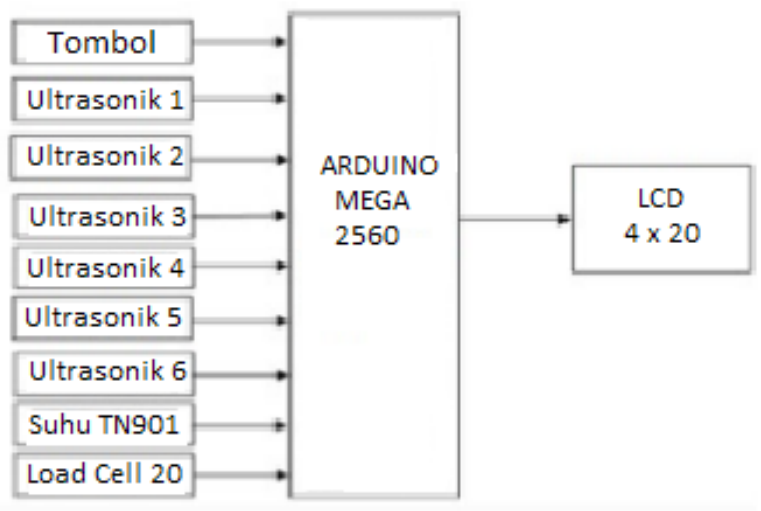

Gambar 4. Blok Diagram Alat Ukur 4 Parameter Kesehatan Batita
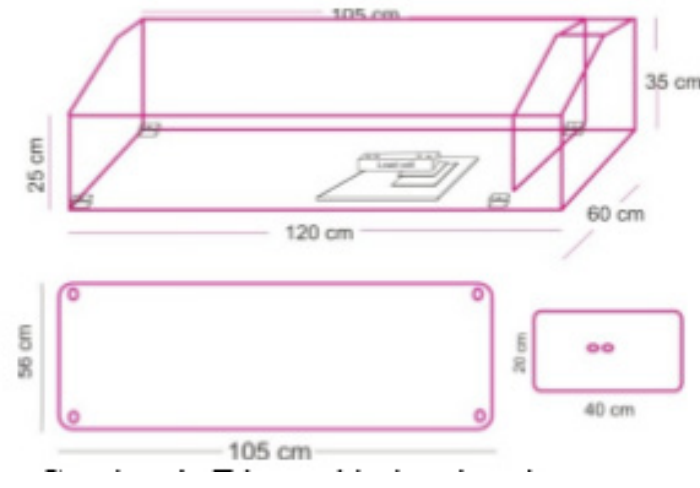

Gambar 5. Dimensi Rancangan Alat Ukur
Berdasarkan blok diagram di Gambar 4 dapat ditunjukkan bahwa input dari mikrokontroler Arduino Mega 2560 menerima data dari input di tombol, 6 sensor ultrasonic, sensor suhu, dan load cell. Output dari hasil pengukuran akan ditampilkan di LCD 4 x 20 .

Dimensi rancangan alat ukur tersebut dilihat pada Gambar 5 (Hartono, 2015).

Berdasarkan Gambar 5, papan multiplek dengan ketebalan 1,8 cm digunakan sebagai boks tempat tidur batita. Dimensi boks adalah 120 x 60 x $35 \mathrm{~cm}$, dengan dimensi tersebut sudah mencukupi karena panjang badan bayi saat berumur 2 tahun rata-rata mencapai $80 \mathrm{~cm}$ sampai $85 \mathrm{~cm}$.

Foto alat ukur tampak atas dapat dilihat pada Gambar 6.

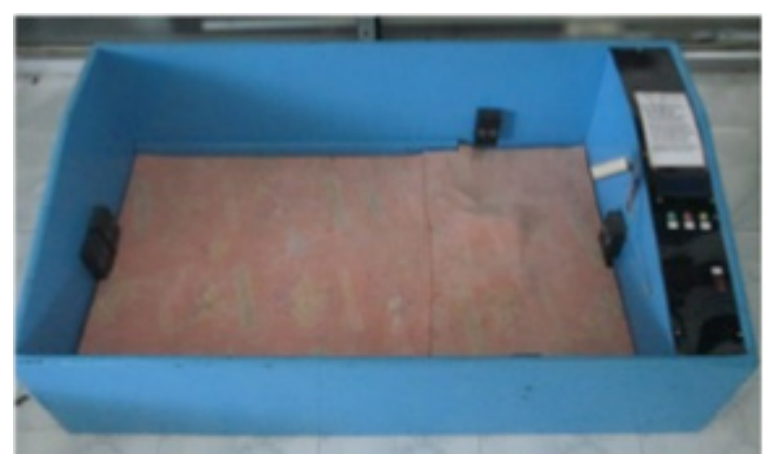

Gambar 6. Foto alat ukur tampak dari atas

Sensor suhunya berupa modul infrared TN901 yang mempunyai rentang pengukuran - $33 \sim 220^{\circ} \mathrm{C}$ dengan jarak 1:1. Adapun Load cell digunakan sebagai sensor berat ditambah rangkaian HX7411. Rangkaian konverter ADC (Analog to Digital Converter) 24 Byte digunakan khusus untuk timbangan. Pengukuran panjang dan lingkar kepala menggunakan sensor ultrasonik dengan masingmasing pengukuran menggunakan 2 buah sensor ultrasonik yang sudah dipasang di atas bagian kepala batita saat telentang.

\section{2) Perancangan Software}

Software/perangkat lunak digunakan untuk menjalankan dan mengendalikan 
semua rancangan perangkat yang telah dibuat. Perangkat lunak yang digunakan pada sistem ini menggunakan bahasa pemrograman dengan bahasa $\mathrm{C}$, sedangkan compiler untuk bahasa $\mathrm{C}$ menggunakan Arduino IDE (Integrated Development Environment) karena di dalamnya telah didesain untuk pemrograman chip ATMEGA 2560 pada board Arduino Mega 2560 yang sudah terdapat berbagai library sehingga programmer dapat menjalankannya dengan mudah. Arduino IDE dilengkapi dengan fitur uploading program yang akan ditanamkan ke chip di board Arduino Mega 2560 tersebut (Lab Elektronika, 2017).

Pada awal program, alat ukur akan menginisialisasi chip ATMEGA 2560 berupa pengaktifan $L C D$, port keluaran, dan masukan. Setelah program inisialisasi dijalankan, maka kemudian akan menjalankan program tampilan yaitu berupa nilai suhu, berat, panjang, dan lingkar kepala batita. Tombol Start digunakan untuk memulai pengukuran. Sedangkan tombol Reset digunakan untuk mereset ulang semua nilai yang telah tertulis sebelumnya. Tombol Pause digunakan untuk menghentikan semua nilai yang telah tertulis, sehingga memudahkan dalam mencatat semua hasil pengukuran.

Rumus perhitungan dibagi menjadi empat bagian yaitu: rumus perhitungan suhu, berat, panjang, dan lingkar kepala.

Perhitungan Suhu menggunakan rumus pada Persamaan 1 (Efendi, 2013; Hartono, 2015; SI Brochure, 2010; Sastry, 2016).

$$
\text { realTemp = tempData: } 16-273,15
$$

Kata tempData adalah nilai digital yang terbaca oleh sensor infrared TN901. Sedangkan $1 / 16^{\circ} \mathrm{C}$ ialah resolusi sensornya, sebagai pembagi tempData.

Suhu teoritis ditentukan dengan mengekstrapolasi hukum gas ideal menggunakan kesepakatan internasional. Jadi, nol absolut diambil sebagai $-273,15^{\circ}$ pada skala Celsius (International System of Unit), yang setara dengan $-459,67^{\circ}$ pada skala Fahrenheit (unit adat Amerika Serikat atau unit Imperial) (SI Brochure, 2010).

Perhitungan Berat Badan

berdasarkan Persamaan 2

(Suryowidagdo, 2013; Hartono, 2015).

$$
\text { Berat }=\text { Berat terukur }- \text { Berat offset }
$$

Dalam pengukuran sesungguhnya menggunakan satuan gram agar lebih presisi dalam pengukurannya berdasarkan Persamaan 3.

$$
\text { Gram }=\text { Berat } / 24
$$

Berat terukur adalah berat yang terbebani pada load cell. Sedangkan berat offset ialah nilai digital yang terbaca oleh sensor load cell. Sedangkan angka 24 menunjukkan skala bit (binary digit) per gram.

Perhitungan Tinggi Badan setiap kelipatan 20 Hs diasumsikan sudah menempuh jarak 6,88 $\mathrm{mm}$. Penghitunga jarak dengan menggunakan sensor ultrasonik dapat dilihat seperti Persamaan 4 (Efendi, 2013; Hartono, 2015).

$$
\operatorname{Jarak}=(6,88 * \Sigma \mathrm{t}) / 2
$$

Nilai jarak masih dalam satuan mm, maka untuk menjadikan $\mathrm{cm}$ maka harus dibagi dengan angka 10. Jika panjang papan adalah $99 \mathrm{~cm}$, maka untuk menghitung panjang badan bayi bisa dihitung dengan Persamaan 5 dan 6.

Panjang = Ultrasonik3 - Ultrasonik1

Ultrasonik 3 = 99 - jarak 
$\Sigma$ t ialah jumlah kelipatan waktu setiap $20 \mu \mathrm{s}$.

$\begin{array}{lll}\text { Perhitungan } & \text { Lingkar } & \text { Kepala } \\ \text { menggunakan } & \text { rumus } & \text { keliling }\end{array}$
lingkaran seperti pada Persamaan 7 (Suryowidagdo, 2013; Hartono, 2015).

\section{Keliling Lingkaran $=\pi . d$}

Berdasarkan dari Persamaan 7, jika lebar papan $50 \mathrm{~cm}$, maka harus mengetahui diameter lingkaran dengan menggunakan Persamaan 8.

\section{d = 50-(ultrasonik4+ultrasonik5)}

$\pi=$ phi sebesar 22/7 atau 3,14. Adapun d ialah diameter lingkaran.

Rumus-rumus tersebut dimasukkan ke dalam script komputasi (perhitungan) di pemrograman bahasa $\mathrm{C}$ yang akan diproses dan dikendalikan oleh prosesor Arduino Mega 2560.

Selanjutnya tim pengabdian masyarakat membuat panduan tentang penggunaan alat ukur yang dibagikan kepada kader posyandu. Lalu tim memberi pelatihan tentang cara pengoperasian alat ukur tersebut kepada kader posyandu sampai mereka benar-benar terampil menggunakannya. Hal tersebut diharapkan dapat menghemat waktu pengukuran sehingga antriannya jadi lebih singkat. Selain itu para kader posyandu bisa segera melaksanakan tugas lainnya di luar posyandu. Adapun pedoman atau panduan dalam menggunakan alat ukur ini ditunjukkan pada Gambar 7.
Berdasarkan panduan pada Gambar 7, dapat diketahui bahwa pedoman penggunaan alat ukur dimulai dari tata cara persiapan dalam menempatkan alat ukur yang sebenarnya cukup berat agar stabil, aman, dan nyaman. Setelah itu alat ukur disambungkan dengan sumber daya listrik agar siap untuk dihidupkan atau dinyalakan. Apabila alat sudah $O N$, maka menunggu status READY di layar $L C D$, lalu pengukuran bisa dilakukan dengan diawali penekanan pada tombol START warna hijau. Pemanggilan batita pun bisa dimulai, kemudian batita pertama ditidurkan di atas alas pada alat ukur dengan posisi kepala di bawah sensor ultrasonic. Lalu kader posyandu bisa menekan tombol PAUSE untuk mendapatkan nilai ukur yang stabil dari keempat parameter kesehatan batita yaitu suhu dalam derajat celcius, berat badan dalam kilogram, panjang badan dalam centimeter, dan lingkar kepala dalam centimeter juga. Keempat nilai tersebut bisa langsung dicatat dalam kertas atau buku daftar hasil ukur berdasarkan nama masing-masing batita yang sudah mendaftar di posyandu pada hari itu.

Proses berikutnya adalah menggendong batita pertama keluar dari bantalan alat ukur untuk dilanjutkan dengan batita kedua dan seterusnya. Sebelum melakukan pengukuran maupun penimbangan untukbatitayang berbeda, maka kader posyandu harus menekan tombol RESET agar semua nilai yang sudah tampil di LCD tadi menjadi nol kembali. Pengukuran tersebut bisa diulangi dari tahap awal sampai akhir secara berulang dengan mengganti obyek ukurnya yaitu batita di posyandu tersebut. Jika semua batita sudah selesai diukur atau ditimbang, maka kader posyandu harus mematikan alat ukur dengan menekan tombol POWER, maka alat ukur 4

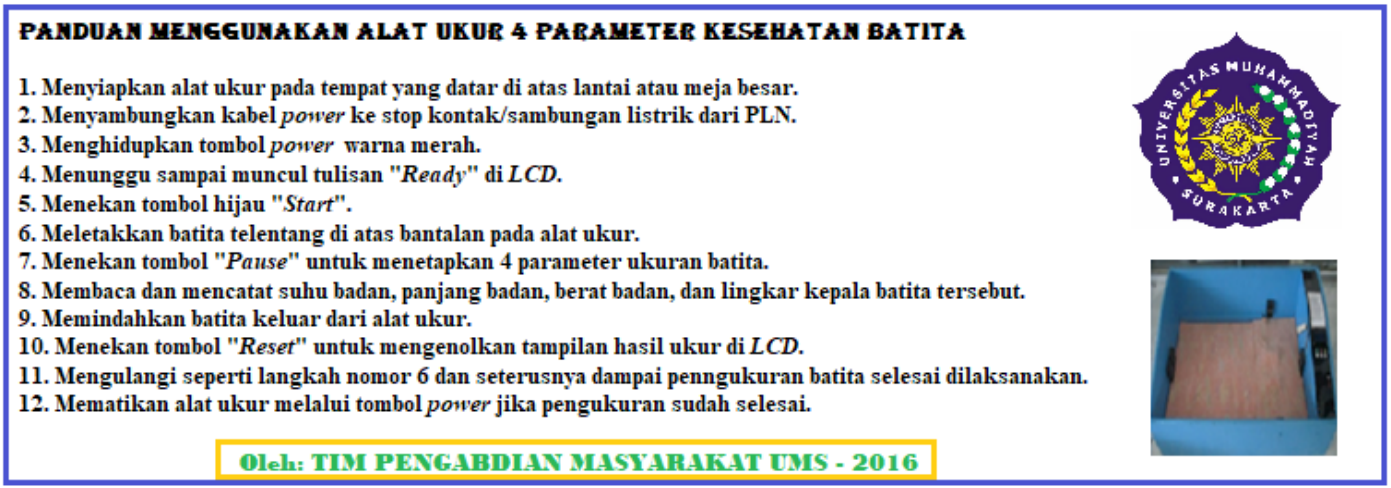

Gambar 7. Panduan dalam Menggunakan Alat Ukur 
parameter kesehatan batita dapat diistirahatkan dan dikembalikan ke tempat penyimpanan semula atau tetap di lokasi khusus pengukuran digital. Semua hasil ukur dari alat ukur digital tersebut sebaiknya dibandingkan juga dengan hasil ukur dari alat ukur konvensional agar lebih meyakinkan. Berdasarkan perbandingan, ada sedikit perbedaan pada hasil ukur dengan persentase error yang cukup kecil. Jadi, hasil ukur dari alat digital dan manual tersebut bisa dikategorikan mendekati sama, hal ini termasuk valid dan akurat dalam hal pengukuran.

Selain pembuatan dan penggunaan alat ukur digital 4 parameter kesehatan batita, tim pengabdian masyarakat ini juga menyiapkan dana PMT untuk balita yang disumbangkan kepada 5 posyandu di wilayah Kelurahan Ngadirejo di awal rapat bersama dengan bidan desa. Selanjutnya untuk sumbangan khusus kepada Posyandu Lestari diberikan sebanyak 3 kali (selama 3 periode kegiatan) yaitu pada Bulan Oktober 2015, serta Februari dan April 2016. Pemberian bantuan tersebut berupa uang untuk menambah kas posyandu yang bisa digunakan untuk membeli bahan baku tambahan gizi bagi balita atau para peserta posyandu. Tambahan makanan bergizi yang biasanya diberikan kepada para balita di posyandu tersebut antara lain adalah bubur santan beras putih, bubur sumsum, bubur kacang hijau, roti, susu, telur, snack, da lain-lain.

Adapun partisipasi pihak posyandu dalam pelaksanaan program pengabdian masyarakat ini adalah memberikan ijin untuk melaksanakan pengabdian masyarakat dengan disaksikan oleh bidan desa setempat beserta para kader posyandunya. Pihak posyandu juga mengatur waktu untuk melaksanakan kegiatan pengabdian masyarakat untuk disepakati bersama pelaksana program di sela-sela kegiatan rutin di posyandu. Posyandu Lestari menyediakan tempat di rumah $\mathrm{Bu}$ Pri untuk melaksanakan kegiatan rutinnya sekaligus untuk meletakkan alat ukur elektronik dan pelatihan serta mengisi kuesioner setelah agenda posyandu selesai.

\section{HASIL DAN PEMBAHASAN}

Tim pengabdian masyarakat di awal persiapannya datang ke Posyandu Lestari selama 5 kali yaitu saat pengujian alat, pelatihan, dan penyampaian sumbangan alat maupun dana PMT (dari akhir 2015 sampai dengan pertengahan 2016). Pelaksanaan dalam Pengabdian Masyarakat ini diawali dengan pertemuan bersama kader dari lima Posyandu yang dihadiri oleh bidan desa (yaitu Bu Wiwih Nihaya Satar, A.Md.Keb.) setempat untuk mencari tahu lebih dalam mengenai permasalahan tentang layanan posyandu per bulan. Gambar 8 memperlihatkan suasana saat ketua tim pengabdian masyarakat mengikuti pertemuan dengan ibu bidan dan kader-kader posyandu se-Kelurahan Ngadirejo.

Selanjutnya tim pengabdian masayarakat memutuskan untuk memilih salah satu posyandu sebagai tempat pengabdian masyarakat, yaitu Posyandu Lestari yang paling dekat dengan Kantor Kelurahan Ngadirejo. Letak Posyandu Lestari dapat dilihat pada denah dan contoh di Gambar 9.

Tempat kegiatan pengabdian masyarakat ini di Posyandu Lestari, Dusun Ngadijayan, Kelurahan Ngadirejo, Kartasura, Sukoharjo (Rumah Ibu Sri Rejeki Suprihati yang akrab dipanggil Bu Pri) dengan Bidan Desa Ibu Wiwih Nihaya Satar, A.Md.Keb.

Pelatihan dipandu oleh ketua tim pengabdian masyarakat dan dua anggota sebagai pendamping pelatihan. Saat pengukuran menggunakan alat ukur digital dapat dilihat pada Gambar 10.

Pengujian alat ukur digital ini sebenarnya diawali dengan penguujian di RSIS (Rumah Sakit Islam Surakarta) sebagai latihan dengan 2 parameter ukur terlebih dahulu. Pengukuran percobaan awal itu untuk memastikan apakah alat ukur digital tersebut bisa berfungsi dengan baik atau tidak dan mendapatkan hasil yang sudah valid atau belum. Percobaan pengukuran di RSIS disaksikan oleh para perawat yang biasa menangani pemeriksaan awal balita sebelum dicek kesehatannya oleh dokter spesialis anak. Proses dan hasil pengukuran batita di RSIS dicatat untuk dijadikan sebagai bahan pertimbangan dalam membuat alat ukur dengan 4 parameter kesehatan sekaligus dalam satu tampilan di LCD. Berdasarkan proses percobaan pengukuran di RSIS, tim pengabdian masyarakat mendapatkan kritik dan saran yang membangun agar alat ukur digital dengan 4 parameter kesehatan bisa terwujud dengan lebih baik lagi. 
Fadlilah, dkk - Peningkatan Kinerja Kader Posyandu ...

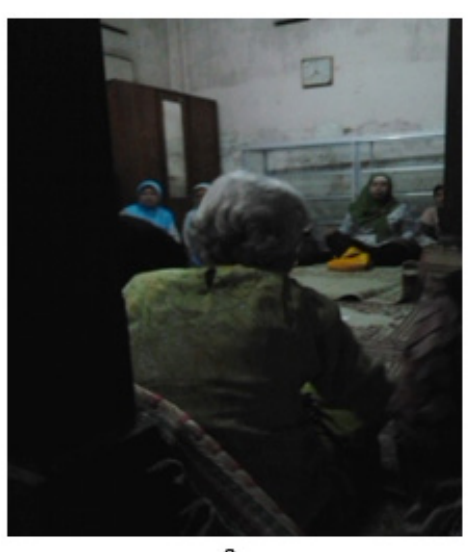

a

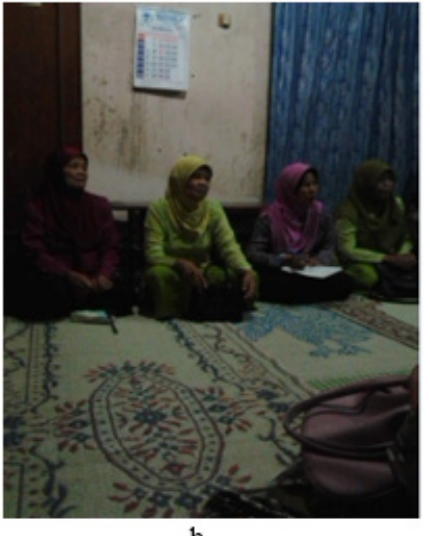

b

Gambar 8. Pertemuan dengan bidan dan kader-kader posyandu

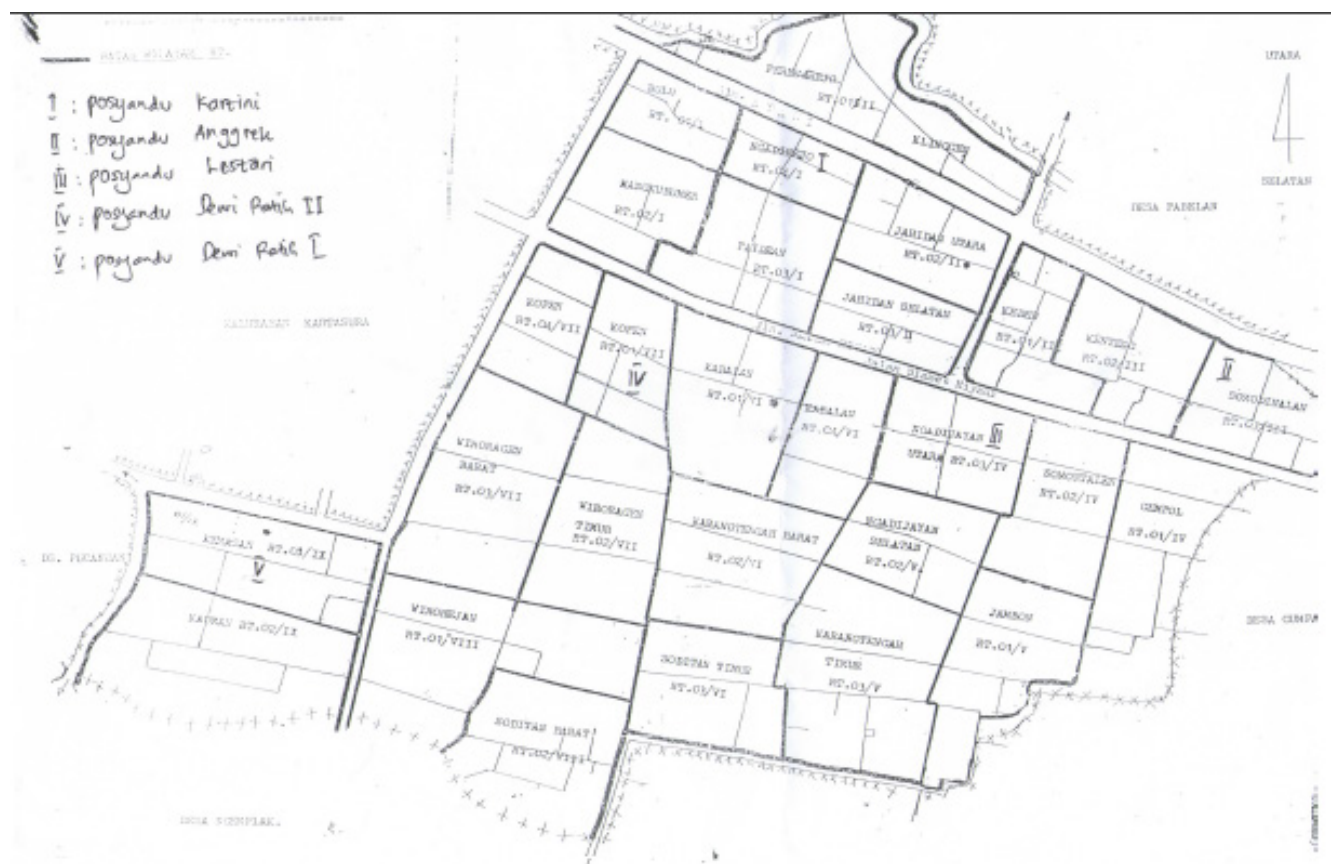

Gambar 9. Lokasi Posyandu

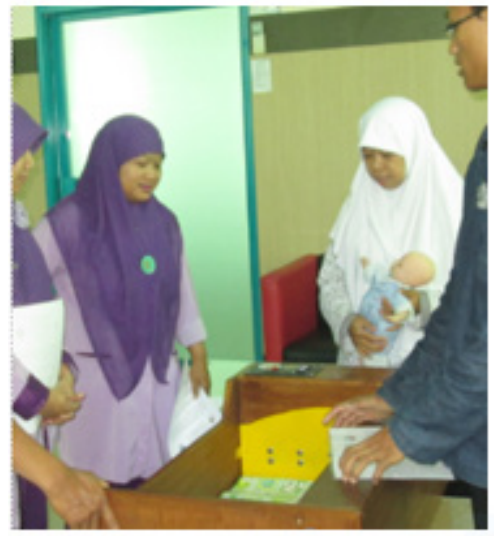

a

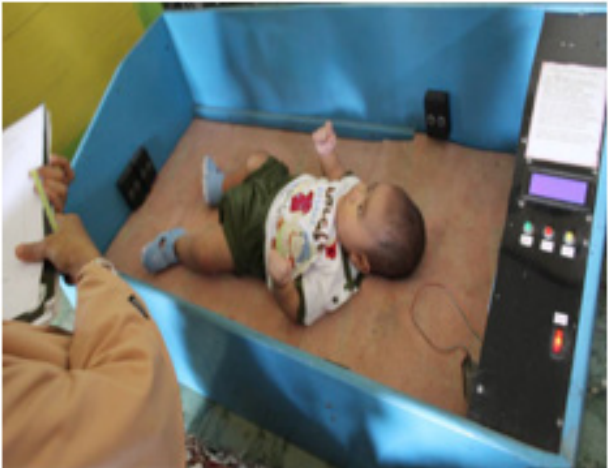

b

Gambar 10. Suasana saat pelatihan pendahuluan di RSIS (a) dan realisasi di Posyandu Lestari (b) 
Fadlilah, dkk - Peningkatan Kinerja Kader Posyandu ...

Selanjutnya hasil sampel pengukuran di Posyandu Lestari dapat dilihat pada Tabel 1, 2, 3, dan 4.

Tabel 1. Hasil Pengukuran Suhu

\begin{tabular}{ccccccc}
\hline No. & Nama & $\begin{array}{c}\text { Usia } \\
\text { (bulan) }\end{array}$ & $\begin{array}{c}\text { Alat di } \\
\text { Posyandu } \\
\text { (Thermometer } \\
\left.\text { air raksa; }{ }^{\circ} \mathrm{C}\right)\end{array}$ & $\begin{array}{c}\text { Alat dari tim } \\
\text { PengMasy } \\
\text { (Sensor suhu } \\
\left.\text { inframerah; }{ }^{\circ} \mathrm{C}\right)\end{array}$ & $\begin{array}{c}\text { Selisih } \\
\left({ }^{\circ} \mathrm{C}\right)\end{array}$ & $\begin{array}{c}\text { Persentase } \\
\text { penyimpangan } \\
(\%)\end{array}$ \\
\hline 1 & Clarisa & 23 & 36,5 & 31 & 5,5 & 15 \\
2 & Safiah & 8,5 & 36,5 & 31 & 5,5 & 15 \\
3 & Safia S. & 6 & 36,5 & 30,9 & 5,6 & 15,3 \\
4 & Helmi & 38 & 36 & 30,4 & 5,6 & 15,5 \\
5 & Nabila & 12 & 37 & 31,7 & 5,3 & 14 \\
6 & Davin & 32 & 36,5 & 31 & 5,5 & 15 \\
7 & Galang & 41 & 37 & 32,3 & & 12,7 \\
\hline
\end{tabular}

Tabel 2. Hasil Pengukuran Berat Badan

\begin{tabular}{ccccccc}
\hline No. & Nama & $\begin{array}{c}\text { Usia } \\
\text { (bulan) }\end{array}$ & $\begin{array}{c}\text { Alat di } \\
\text { Posyandu } \\
\text { (Timbangan; } \\
\text { kg) }\end{array}$ & $\begin{array}{c}\text { Alat dari tim } \\
\text { PengMasy } \\
\text { (Loadcell; } \\
\text { gram) }\end{array}$ & $\begin{array}{c}\text { Selisih } \\
\text { (kg) }\end{array}$ & $\begin{array}{c}\text { Persentase } \\
\text { penyimpangan } \\
\text { (\%) }\end{array}$ \\
\hline 1 & Clarisa & 23 & 12,3 & 12000 & 0,3 & 2,4 \\
2 & Safiah & 8,5 & 6,7 & 6700 & 0 & 0 \\
3 & Safia S. & 6 & 6 & 6000 & 0 & 0 \\
4 & Helmi & 38 & 11,7 & 12500 & 0,8 & 6,8 \\
5 & Nabila & 12 & 8,2 & 8200 & 0 & 0 \\
6 & Davin & 32 & 13 & 12600 & 0,6 & 4,6 \\
7 & Galang & 41 & 14 & 15000 & 1 & 7,5 \\
\hline
\end{tabular}

Tabel 3. Hasil Pengukuran Panjang Badan

\begin{tabular}{ccccccc}
\hline No. & Nama & $\begin{array}{c}\text { Usia } \\
\text { (bulan) }\end{array}$ & $\begin{array}{c}\text { Alat di Posyandu } \\
\text { (Alat ukur } \\
\text { panjang badan; } \\
\text { cm) }\end{array}$ & $\begin{array}{c}\text { Alat dari tim } \\
\text { PengMasy } \\
\text { (Sensor } \\
\text { ultrasonik; cm) }\end{array}$ & $\begin{array}{c}\text { Selisih } \\
\text { (cm) }\end{array}$ & $\begin{array}{c}\text { Persentase } \\
\text { penyimpangan } \\
\text { (\%) }\end{array}$ \\
\hline 1 & Clarisa & 23 & 93 & 91 & 2 & 2,1 \\
2 & Safiah & 8,5 & 65 & 65 & 0 & 9 \\
3 & Safia S. & 6 & 62 & 62 & 0 & 0 \\
4 & Helmi & 38 & 85 & 82 & 3 & 3,5 \\
5 & Nabila & 12 & 72 & 72 & 0 & 0 \\
6 & Davin & 32 & 90 & 91 & 1 & 1,1 \\
7 & Galang & 41 & 92 & 93 & 1 & 1,08 \\
\hline
\end{tabular}


Tabel 4. Hasil Pengukuran Lingkar Kepala

\begin{tabular}{llccccc}
\hline No. & Nama & $\begin{array}{c}\text { Usia } \\
\text { (bulan) }\end{array}$ & $\begin{array}{c}\text { Alat di Posyandu } \\
\text { (Alat ukur lingkar } \\
\text { kepala; cm) }\end{array}$ & $\begin{array}{c}\text { Alat dari tim PengMasy } \\
\text { (Sensor ultrasonik; cm) }\end{array}$ & $\begin{array}{c}\text { Selisih } \\
\text { (cm) }\end{array}$ & $\begin{array}{c}\text { Persentase } \\
\text { penyimpangan } \\
\text { (\%) }\end{array}$ \\
\hline 1 & Clarisa & 23 & 44 & 40 & 4 & 9,09 \\
2 & Safiah & 8,5 & 41 & 100 & 59 & 143 \\
3 & Safia S. & 6 & 39,5 & 97 & 57,5 & 145 \\
4 & Helmi & 38 & 45,5 & 53 & 7,5 & 16,4 \\
5 & Nabila & 12 & 42 & 37 & 5 & 11,9 \\
6 & Davin & 32 & 45 & 47 & 2 & 4,4 \\
7 & Galang & 41 & 45,5 & 43 & 2,5 & 5,4 \\
\hline
\end{tabular}

Pada Tabel 1 dapat diketahui bahwa dari ketujuh balita yang suhu badannya diukur menggunakan 2 alat pada masing-masing parameter ukur menghasilkan selisih ukur sebesar $5,3{ }^{\circ} \mathrm{C}$ dan persentase error $14,6 \%$. Adanya selisih tersebut bisa jadi karena pada saat pengukuran menggunakan alat di posyandu maupun dari tim pengabdian masyarakat, balita yang diukur merasa takut ataupun dalam kondisi bergerak.

Pada Tabel 2 masih menggunakan obyek yang sama dengan responden pada Tabel 1 dapat diketahui bahwa rata-rata pengukuran berat badan lebih kecil daripada rata-rata hasil ukur suhu yaitu $0,38 \mathrm{~kg}$ saja dengan persentase error 3,04\%.

Pada Tabel 3, rata-rata selisih hasil pengukuran adalah $1 \mathrm{~cm}$ dengan persentase penyimpangan sebesar 1,1\%. Hal ini berarti kedua alat menghasilkan pembacaan ukur yang relatif hampir sama.

Pada Tabel 4 menunjukkan bahwa rata-rata selisih pengukuran masih lumayan besar yaitu $19,6 \mathrm{~cm}$ atau mengalami error 47,6\%. Hal itu bisa diartikan bahwa hasil pengukuran menggunakan alat dari tim pengabdain masyarakat masih belum valid dan perlu perbaikan alat untuk selanjutnya.

Selisih hasil ukur digital yang dibuat oleh tim pengabdian masyarakat jika dibandingkan dengan alat ukur yang menggunakan alat-alat manual di posyandu itu berbeda-beda pada tiap parameter kesehatan batita. Berdasarkan dari 7 responden batita di Tabel 1, 2, 3, dan 4 dapat diketahui bahwa rata-rata selisih hasil ukur suhu adalah $5,3^{\circ} \mathrm{C}$, rata-rata selisih hasil ukur panjang badan yaitu $1 \mathrm{~cm}$, rata-rata selisih hasil ukur berat badan ialah 0,38 , dan rata-rata selisih hasil ukur lingkar kepala yakni 19,6 cm. Khusus untuk Ananda Safiah, Safia, dan Nabila pada pengukuran panjang dan berat badan tidak ada selisih hasil ukurnya atau bernilai nol. Hal tersebut menunjukkan bahwa posisi batita pada saat pengukuran itu mempengaruhi valid atau tidaknya hasil ukur tersebut. Jadi, alat ukur digital untuk 4 parameter kesehatan batita ini sudah bisa dijadikan alternatif untuk pengukuran batita di posyandu terutama apabila peserta batita pada hari tersebut sangat banyak, sebab alat ukur ini bisa menampilkan hasil ukurnya rata-rata di bawah 1 menit sudah tampil di LCD.

Agenda pengabdian masyarakat ini berikutnya adalah penyerahan bantuan dana PMT yang dilakukan oleh ketua tim pengabdian masyarakat dengan disaksikan oleh para kader Posyandu Lestari. Dana itu diterima oleh Ketua Posyandu Lestari yaitu Ibu Pri dan kader posyandu di salah satu rumah kader posyandu saat sosialisasi awal. Adapun penyerahan alat ukur digital di Posyandu Lestari dan RSIS ditandai dengan penandatanganan berita acara bersama tim pengabdian masyarakat. Tahapan selanjutnya tim mendistribusikan kuesioner kepada para perawat RSIS dan kader-kader Posyandu Lestari untuk mengetahui respon dari mereka terhadap kegiatan pengabdian masyarakat ini. Hasil kesimpulan pengisian kuesioner tentang alat ukur 4 parameter kesehatan balita di Posyandu Lestari ditunjukkan pada Tabel 5. 
Tabel 5. Hasil kesimpulan pengisian kuesioner

\begin{tabular}{|c|c|c|c|c|c|c|c|}
\hline \multirow[t]{2}{*}{ No. } & \multirow{2}{*}{$\begin{array}{l}\text { Rangkuman Pernyataan untuk Responden } \\
\text { tentang Alat Ukur Tim Pengabdian Masyarakat }\end{array}$} & \multicolumn{5}{|c|}{$\begin{array}{c}\text { Jumlah Responden } \\
\text { Memilih Per Nilai }\end{array}$} & \multirow{2}{*}{$\begin{array}{c}\text { Total } \\
\text { Responden }\end{array}$} \\
\hline & & SB & $\mathrm{B}$ & $\mathrm{C}$ & $\mathrm{K}$ & SK & \\
\hline 1 & Kenyamanan alat & 3 & 3 & 3 & 2 & 3 & 14 \\
\hline 2 & Keamanan alat & 4 & 3 & 3 & 3 & 3 & 16 \\
\hline 3 & Akurasi hasil ukur suhu & 2 & 3 & 2 & 1 & 2 & 10 \\
\hline 4 & Akurasi hasil ukur berat & 2 & 2 & 2 & 2 & 2 & 10 \\
\hline 5 & Akurasi hasil ukur panjang & 2 & 2 & 2 & 2 & 2 & 10 \\
\hline 6 & Akurasi hasil ukur lingkar kepala & 2 & 2 & 2 & 2 & 2 & 10 \\
\hline 7 & Akurasi hasil ukur 4 parameter & 2 & 2 & 2 & 3 & 2 & 11 \\
\hline 8 & Kemudahan dalam pemakaian & 3 & 3 & 4 & 3 & 2 & 15 \\
\hline 9 & Kecepatan dalam menampilkan hasil ukur suhu & 3 & 3 & 4 & 3 & 3 & 16 \\
\hline 10 & Kecepatan dalam menampilkan hasil ukur berat & 3 & 3 & 3 & 3 & 3 & 15 \\
\hline 11 & Bentuk fisik alat berdasarkan tampilan luarnya & 3 & 3 & 2 & 3 & 2 & 13 \\
\hline 12 & Bentuk fisik alat berdasarkan ukurannya & 3 & 3 & 3 & 3 & 3 & 15 \\
\hline 13 & Bermanfaat di dunia medis & 3 & 3 & 4 & 3 & 2 & 15 \\
\hline
\end{tabular}

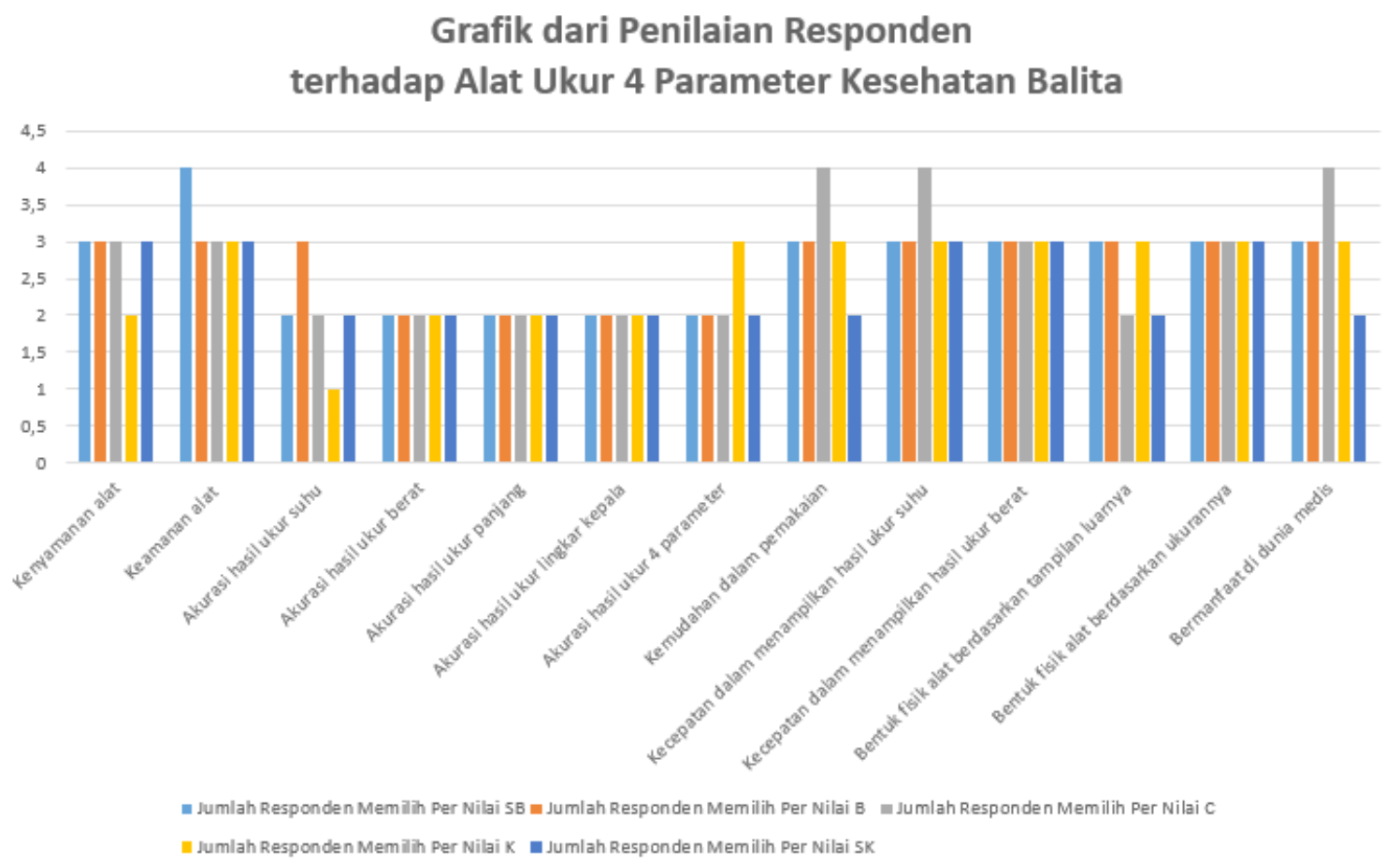

Gambar 11. Grafik Hasil Penilaian Responden terhadap Alat Ukur yang Disumbangkan

Berdasarkan Tabel 5 dapat diketahui bahwa sebenarnya jumlah responden ada 16 orang (dari kader Posyandu Lestari dan pegawai RSIS), namun tidak semua pernyataan dinilai karena ada yang abstain atau tidak memberikan respon. Selain itu, pada saat pengukuran menggunakan alat dari tim pengabdian masyarakat, kader posyandu tersebut menyebar untuk melaksanakan tugas masing-masing sehingga belum sempat melihat secara detail cara kerja dan hasil pengukuran dari alat tersebut. Pernyataan yang secara penuh ditanggapi oleh responden adalah perihal keamanan alat dan kecepatan dalam menampilkan hasil ukur suhu 
yaitu di pernyataan nomor 3 dan 9. Sedangkan grafik dari hasil tanggapan responden tersebut dapat dilihat pada Gambar 11.

Gambar 11 menunjukkan bahwa ada 5 kategori penilaianyaituSB (SangatBaik), B (Baik), C (Cukup), K (Kurang), dan SK (Sangat Kurang) terhadap alat ukur 4 parameter kesehatan balita. Tanggapan dari kader Posyandu Lestari sangat beragam sesuai dengan pengalaman mereka saat menggunakan alat ukur dari tim pengabdian masyarakat UMS. Penilaian yang terbanyak dari responden adalah keamanan alat yang sangat baik serta cukup dalam hal kemudahan menggunakannya, kecepatan dalam menampilkan hasil ukur suhu, dan bermanfaat di dunia medis, masing-masing dipilih oleh 4 responden. Sedangkan penilaian paling sedikit adalah pada topik tentang kurangnya akurasi ata kecermatan dalam hasil ukur suhu.

Lalu resume dari kuesioner essay berupa beberapa kritik dan saran konstruktif dari kader-kader dan bidan di Posyandu Lestari terhadap alat ukur ini antara lain ialah bahwa alat ukur tersebut sebaiknya diberi alarm saat pengukuran selesai, sehingga bisa mengingatkan kader-kader posyandu untuk segera melanjutkan ke pengukuran yang lain. Selain itu juga hendaknya alat itu diberi warna yang cerah agar lebih menarik dan pada sisi boks diberi mainan anak-anak sehingga anak tidak merasa ketakutan saat proses pengukuran berlangsung. Bentuk boksnya pun lebih baik dibuat lebih ringan dan mudah untuk dibawa atau fleksibel) sehingga bisa terlihat seperti mainan anak-anak. Terkait dengan hasil ukur, alangkah lebih baik lagi jika distabilkan, jadi, nilainya tidak mudah berubah-ubah.

Di sisi lain, para paramedis di RSIS, kaderkader posyandu di Kelurahan Ngadirejo serta bu bidan dan kader Posyandu Lestari khususnya merasa senang dengan kehadiran tim pengabdian masyarakat sekitar 5 bulan di Posyandu Lestari tersebut. Mereka mengucapkan terima kasih atas pengalaman, pelatihan, dan bantuan yang diberikan di Posyandu Lestari dan juga 4 posyandu yang lain. Tim pengabdian masyarakat dan juga pihak posyandu berharap agar kegiatan ini bisa ditindaklanjuti dengan kegiatan berikutnya yang juga lebih bermanfaat bagi semua pihak.

\section{Kesimpulan}

Pengabdian masyarakat ini didahului dengan percobaan pengukuran di RSIS dan rapat awal dengan para kader di 5 posyandu seKelurahan Ngadirejo. Kemudian tim pengabdian masyarakat menindaklanjuti untuk melakukan kegiatan intensif di Posyandu Lestari yang bermanfaat untuk membantu para kader posyandu dalam melaksanakan aktivitas rutin bulanannya sehingga mereka bisa meningkat kapasitasnya. Para kader posyandu dan orang tua batita merasa senang dengan kehadiran alat bantu ukur tersebut. Pada saat pengukuran/ penimbangan batita menggunakan alat ukur digital yang sudah disumbangkan ke Posyandu Lestari dengan didahului pelatihan terhadap kader posyandu agar lebih terampil dalam menggunakannya. Hasil ukur tentang 4 parameter batita tersebut sudah cukup valid, praktis, dan menghemat waktu walaupun kadang nilai ukurnya belum stabil terutama dalam hal parameter suhu. Untuk selanjutnya, tim pengabdian masyarakat akan mengecek dan memantau pemakaian alat ukur tersebut agar lebih baik lagi. Selain itu, pengabdian masyarakat ini diakhiri dengan pelayanan tambahan gizi balita melalui pemberian dana bantuan PMT. Tim pengabdian masyarakat UMS berharap agar kegiatan tersebut dapat meningkatkan kinerja kader Posyandu dan kualitas pelayanannya.

Saran dari bidan dan para kader Posyandu Lestari yang didapat saat pengabdian masyarakat ini ialah sebaiknya alat ukur digital dibuat lebih ringan, agar kader posyandu tidak kesulitan saat mengangkat ke tempat pengukuran. Selain itu warna cat boks alat ukur sebaiknya lebih cerah lagi dan diberi ornament mainan anak agar batita merasa nyaman dan tidak takut saat proses pengukuran berlangsung. Selanjutnya tim pengabdian masyarakat diharapkan turut hadir saat penimbangan batita pada tiap bulannya terutama di Posyandu Lestari. Harapan dari para kader posyandu di Kelurahan Ngadirejo agar kegiatan tersebut dilanjutkan juga di posyandu yang lain sehingga lebih banyak manfaatnya.

\section{PERSANTUNAN}

Pada pengabdian masyarakat ini, kami mengucapkan puji syukur kehadirat Allah 
SWT yang telah memberikan karuniaNYA sehingga kami dapat menjalankan serangkaian pengabdian masyarakat ini dengan baik. Tak lupa pula kami haturkan terima kasih kepada UMS yang telah mendanai pengabdian masyarakat ini, Ibu Wiwih Nihaya Satar (bidan), Ibu Pri (Ketua Posyandu Lestari), beserta seluruh kader Posyandu Lestari, dan kader-kader 5 Posyandu di Kelurahan Ngadirejo atas bantuan dan perhatiannya. Selain itu juga terima kasih kepada Dokter Lucy (dokter spesialis anak) dan seluruh perawat bagian anak di RSIS yang turut membantu persiapan sebelum pengabdian masayarakat di Posyandu Lestari. Semoga Allah SWT memberi pahala yang terbaik bagi semua pihak yang telah membantu terlaksananya pengabdian masyarakat ini.

\section{REFERENSI}

Al Azizah, W., Agustina, I. F. (2017). Partisipasi Masyarakat dalam Posyandu di Kecamatan Sidoarjo. JKMP (Jurnal Kebijakan dan Manajemen Publik), 5 (2), September 2017, 229-244 ISSN 2338445X (print), ISSN 2527-9246 (online). http://ojs.umsida.ac.id/index.php/ikmp. https://doi. org/10.21070/jkmp.v5i2.1315.

Efendi, E.T. (2013). Instrumentasi Alat Ukur Suhu dan Panjang Badan Bayi Berbasis Mikrokontroler ATMEGA 16. http://eprints.ums.ac.id/26240/9/NASKAH PUBLIKASI ILMIAH.pdf

Fitriyanti, F., Mulyati, T. (2012). Pengaruh Pemberian Makanan Tambahan Pemulihan (PMT-P) terhadap Status Gizi Balita Gizi Buruk di Dinas Kesehatan Kota Semarang Tahun 2012. Journal of Nutrition College, Volume 1, Nomor 1, Tahun 2012, Halaman 373-381 Online di http://e-journal-s1.undip. ac.id/index.php/jnc

Hartono, S.R. (2015). Rancang Bangun Alat Ukur Suhu, Panjang, Berat, serta Lingkar Kepala Bayi Berbasis Arduino Mega. http://eprints.ums.ac.id/34543/1/Naskah\%20publikasi\%20ilmiah\%20sohart.pdf

Lab Elektronika. (2017). Arduino Mega 2560 Mikrokontroler ATmega 2560. www.labelektronika. com/2017/02/arduino-mega-2560-mikrokontroler.html

Mulat, T.C. (2017). Peran Kader Posyandu terhadap Upaya Peningkatan Status Gizi Balita (3-5) Tahun di Wilayah Kerja Puskesmas Batua Kota Makassar. Jurnal Ilmiah Kesehatan Sandi Husada. https:// media.neliti.com/media/publications/283274-peran-kader-posyandu-terhadap-upaya-peni1960469a.pdf

Muninjaya, Gde. (2004). Manajemen Kesehatan. Jakarta EGC, Edisi 2 Cetakan 1. http://pustakaaceh. perpusnas.go.id/detail-opac?id=34530.

Sastry, S. (2016). Absolute Zero Occurs in Black Holes. Journal of Modern Physics, 2016, 7, 13751377 Published Online July 2016 in SciRes. http://www.scirp.org/journal/jmp http://dx.doi. org/10.4236/jmp.2016.711124.

SI Brochure. (2010). Unit of Thermodynamic Temperature (Kelvin). 8th edition. Bureau International des Poids et Mesures. 13 March 2010 [1967]. pp. Section 2.1.1.5.

Suryowidagdo, E.P. (2013). Instrumentasi Alat Ukur Berat dan Lingkar kepala Bayi Berbasis Mikrocontroler ATMEGA16. http://eprints.ums.ac.id/27181/1/HALAMAN DEPAN.pdf

Tim Pusdatin. (2016). Situasi Balita Pendek. Pusat Data dan Informasi Kementrian Kesehatan Republik Indonesia. ISSN2442-7659.

Utami, Y.R.W., Fitriasih, S.H., Siswanti, S. (2014). Peranan Keaktifan Ibu dalam Kegiatan Posyandu dengan Status Gizi Balita untuk Menunjang Sistem Informasi Perkembangan Balita. Jurnal Ilmiah SINUS. ISSN: 1693-1173.

https://p3m.sinus.ac.id > index.php > e-jurnal_SINUS > article > download 